\title{
ASPEK-ASPEK HUKUM KELUARGA DALAM AWIG-AWIG DESA PAKRAMAN ${ }^{I}$
}

\author{
Oleh: \\ I Ketut Sudantra ${ }^{2}$, I Made Walesa Putra ${ }^{3}$, Yuwono ${ }^{4}$
}

\begin{abstract}
Abstrack
This research is a normative research that aimed to identify family law aspects on legal regulation that created by customary law society of desa pakraman in Bali. Those regulation usually known as awig-awig desa pakraman. This research used nine awig-awig desa pakraman that represented all regencies on Bali Province. The result shows that family law aspect is regulated on a specific chapter of awig-awig desa pakraman titled: Sukerta Tata Pawongan. This chapter regulated relationship between human, specially on family relation. Family law aspects that regulated on this chapter covered: (1) matter of marriage (indik pawiwahan), (2) matter of divorce (indik nyapian), (3) matter of lineage (indik sentana), and (4) matter of inheritance (indik warisan).
\end{abstract}

Keywords: family law, awig-awig, customary law society, desa pakraman.

\begin{abstract}
Abstrak
Penelitian ini adalah penelitian hukum normatif yang bertujuan untuk mengidentifikasi aspek-aspek hukum keluarga dalam peraturan-peraturan hukum yang dibuat oleh kesatuan masyarakat hukum adat desa pakraman di Bali. Peraturan-peraturan tersebut lazim disebut awig-awig desa pakraman. Penelitian dilakukan terhadap sembilan awig-awig desa pakraman yang mewakili seluruh kabupaten/kota yang ada di Provinsi Bali. Hasil penelitian menunjukkan bahwa aspek-aspek hukum keluarga diatur dalam awig-awig desa pakraman dalam satu bab khusus yang berjudul: Sukerta Tata Pawongan. Bab ini mengatur hubungan antara sesama manusia khususnya kehidupan bersama dalam keluarga. Aspekaspek hukum yang diatur dalam bab ini meliputi: (1) prihal perkawinan (indik pawiwahan), (2) prihal perceraian (indik nyapian), (3) prihal anak keturunan (indik sentana), dan (prihal pewarisan (indik warisan).
\end{abstract}

Kata Kunci: hukum keluarga, awig-awig, kesatuan masyarakat hukum adat, desa pakraman

\footnotetext{
Artikel ini berasal dari penelitian yang dibiayai dari Dana SP DIPA (2015) Program Studi Kenotaroiatan PPS Unud., dan mengucapkan terimakasih kepada Kepala Program Studi Kenotariatan PPS Unud yang telah memfasilitasi penelitian ini.

2 Penulis pertama adalah dosen pada Program Studi Ilmu Hukum Fakultas Hukum Unud; dosen Program Studi Magister (S2) Ilmu Hukum PPS Unud; dosen Program Magister (S2) Kenotariatan PPS Unud, Denpasar. Alamat Jalan Muding Mekar Gang Gadung No. 8, Kerobokan Kaja, Kuta Utara, Badung. Email: sudantra01@yahoo.co.id

3 Penulis kedua adalah dosen pada Program Studi Ilmu Hukum Fakultas Hukum Unud, Denpasar. Alamat: Jl. Gn. Batur Perum Nusa Bumi Ayu 7a Denpasar. Email: mdwalesaputra@yahoo.com

4 Penulis ketiga adalah dosen pada Program Studi Ilmu Hukum Fakultas Hukum Unud, Denpasar. Alamat: Jl. P. Saelus I No.6 Denpasar. Email: yumono@unud.ac.id
} 


\section{PENDAHULUAN}

\subsection{Latar Belakang}

Sampai saat ini bangsa Indonesia belum mempunyai hukum keluarga yang bersifat nasional, kecuali pada bidang hukum perkawinan ${ }^{5}$. Walaupun sudah pernah ada upaya untuk merumuskan hukum kekeluargaan nasional, tetapi karena kondisi sosial budaya masyarakat Indonesia yang hiterogen, sampai saat ini belum dapat dibentuk hukum kekeluargaan nasional. Bagi masyarakat adat Bali (etnis Bali yang berama Hindu), hukum yang berlaku di bidang hukum keluarga adalah Hukum Adat Bali. Windia dan Sudantra merumuskan Hukum Adat bali tersebut sebagai "kompleks norma-norma, baik dalam wujudnya yang tertulis maupun tidak tertulis, berisi perintah, kebolehan dan larangan, yang mengatur kehidupan masyarakat bali yang menyangkut hubungan antara sesama manusia, hubungan manusia dengan lingkungan alamnya, dan hubungan manusia dengan Tuhannya"'

Dari pengertian di atas, maka dapat diketahui bahwa hukum yang berlaku bagi masyarakat adat Bali dibidang kekeluargaan adalah hukum

Sejak diberlakukannya Undang-undang Nomor 1 Tahun 1974 tentang Perkawinan Bangsa Indonesia telah mempunyai hukum yang bersifat nasional walaupun undang-undang tersebut masih memberi peluang berlakunya keanekaragaman hukum, yaitu hukum agama dan hukum adat.

6 Wayan P. Windia dan Ketut Sudantra, 2006, Pengantar Hukum Adat Bali, Denpasar: Lembaga Dokumentasi dan Publikasi Fakultas Hukum Universitas Udayana, hlm. 6. adat Bali di mana wujudnya (1) ada yang tertulis; dan (2) ada yang tidak tertulis. Hukum adat Bali yang wujudnya tertulis bukanlah dalam pengertian "tertulis" sebagaimana bentuk peraturan perundang-undangan seperti tertulis dalam bentuk peraturan perundang-undangan Republik Indonesia, melainkan mempunyai wujud "tertulis", misalnya dalam bentuk paswara raja-raja ataupun dalam bentuk awig-awig tertulis.

Mengingat hukum adat Bali sebagian wujudnya tidak tertulis, maka untuk dapat mengetahui hukum adat yang senyatanya berlaku, idealnya orang harus hidup dan melakukan penelitian di tengah-tengah masyarakat di mana hukum adat itu berlaku. Dengan demikian hukum adat dapat diidentifikasi dari pola-pola kelakuan masyarakat yang ajeg. Akan tetapi, apabila cara itu tidak dapat dilakukan, para akademisi dan praktisi hukum dapat mengenali hukum adat dari sumber-sumber tertulis di mana hukum adat telah dicatat atau didokumentasikan. Salah satu sumber hukum adat Baliyang wujudnya tertulis adalah awig-awig desa pakraman. Menurut Peraturan Daerah Provinsi Bali Nomor 3 Tahun 2001 sebagaimana telah diubah dengan Peraturan Daerah Nomor 3 Tahun 2003, awig-awig desa pakraman adalah aturan-aturan yang dibuat oleh desa pakraman yang dipakai sebagai pedoman dalam pelaksanaan tri hita karana. Peraturan Daerah tersebut tidak secara ekplisit menjelaskan konsep tri hita karana, 
tetapi secara umum telah dipahami bahwa tri hita karana menyangkut tiga aspek hubungan yang harus dijaga keseimbangannya, yaitu (1) hubungan antara sesama manusia (pawongan), (2) hubungan antara manusia dengan lingkungan alamnya (palemahan), dan (3) hubungan antara manusia dengan Tuhannya (parhyangan) ${ }^{7}$ Desa pakraman sendiri adalah kesatuan masyarakat hukum adat teritorial di Bali yang mempunyai tatanan hukum sendiri dalam mengatur kehidupan warganya..

Mengacu pada Buku Pedoman/ Teknis Penyusunan Awig-awig dan Keputusan Desa Adat yang dikeluarkan oleh Biro Hukum Setda Propinsi Bali (2001), ada dua aspek hubungan antara sesama manusia yang menjadi substansi awig-awig desa pakraman, yaitu (1) bidang kehidupan bersama dalam keluarga yang diatur dalam bab Sukerta Tata Pawongan; dan (2) aspek kehidupan bersama dalam masyarakat yang diatur dalam bab Sukerta Tata Pakraman $^{8}$. Dilihat dari pembidangan itu, aspek-aspek hukum yang mengatur kehidupan keluarga termasuk lingkup bidang kehidupan bersama dalam keluarga (Sukerta Tata Pawongan)

Dengan demikian, untuk mengetahui pengaturan aspek hukum

\footnotetext{
Lihat Keputusan Seminar Kesatuan Tafsir Terhadap Aspek-aspek Agama Hindu, dalam: I Gusti Ngurah Sudiana dan I Made Artha, 2006, Samhita Bhisama Parisada Hindu Dharma Indonesia, Denpasar: Parisada Hindu Dharma Indonesia Provinsi Bali, hlm. 91.

8 Biro Hukum Setda Provinsi Bali, 2001, Pedoman/Teknis Penyusunan Awig-awig dan Keputusan Desa Adat, tanpa nama penerbit.
}

keluarga menurut hukum adat Bali maka hal itu dapat diidentifikasi dengan melihat pengaturannya dalam awig-awig desa pakraman. Problem yang harus dihadapi dalam usaha mempelajari hukum adat Bali sebagaimana yang tercantum dalam awig-awig desa pakraman adalah fakta bahwa desa pakraman yang ada di Bali berjumlah ribuan ${ }^{9}$. Sebagaimana dipahami bahwa setiap desa pakraman berhak mengurus rumah tangganya sendiri sehingga mempunyai otonomi dalam membuat awig-awig. Kondisi ini memungkinkan bahwa bisa saja pengaturan aspek-aspek hukum keluarga berbeda antara awig-awig desa pakraman yang satu dengan pengaturannya dalam awig-awig desa pakraman lainnya, sehingga menjadi permasalahan tersendiri untuk dapat mengetahui mengenai hukum keluarga menurut hukum adat Bali versi awigawig desa pakraman.

Berdasarkan fakta tersebut, maka penting dan relevan diadakan penelitian terhadap awig-awig desa pakraman, terutama awig-awig desa pakraman yang tertulis. Dengan mengadakan penelitian terhadap awig-awig desa pakraman maka akan diketahui secara umum aspek-aspek hukum keluarga yang diatur dalam awig-awig desa pakraman.

Data terkahir menunjukkan bahwa desa pakraman yang ada di Bali mencapai 1488 desa. Lihat: Badan Perencanaan Pembangunan Daerah Bali Pemerintah Provinsi Bali, 2015, Data Bali Membangun 2014, hlm. V.1 


\subsection{Perumusan Masalah}

Fokus kajian dalam tulisan ini membahas permasalahan sebagai berikut:

1. Apakah aspek-aspek hukum keluarga diatur dalam awig-awig desa pakraman?

2. Bagaimana pengaturan substansi aspek-aspek hukum keluarga dalam awig-awig desa pakraman?

\subsection{Tujuan Penelitian}

Secara umum penelitian ini bertujuan untuk mengkaji pengaturan aspek-aspek hukum keluarga dalam awig-awig desa pakraman. Secara khusus, penelitian ini ditujukan untuk mengetahui: (1) eksistensi hukum keluarga dalam awig-awig desa pakraman; (2) pengaturan substansi aspek-aspek hukum keluarga dalam awig-awig desa pakraman.

\section{METODE PENELITIAN}

Permasalahan dalam penelitian ini dikaji dengan menggunakan metode penelitian hukum normatif, dengan mengandalkan awig-awig (tertulis) desa pakraman sebagai bahan hukum primer. Untuk dapat memahami dan menjelaskan informasi yang diperoleh dari awigawig tersebut, dalam penelitian ini juga digunakan bahan-bahan hukum sekunder, terutama literatur-literatur hukum adat, khususnya hukum adat Bali. Mengingat awig-awig desa pakraman ditulis dalam bahasa Bali, tak terhindarkan juga dalam penelitian ini digunakan bahan non-hukum, yaitu Kamus Bahasa Bali yang dimanfaatkan untuk menjelaskan istilah-istilah atau pun konsep-konsep yang dimuat dalam awig-awig desa pakraman atau pun yang ditemukan dalam literaturliteratur hukum adat Bali.

Pengumpulan bahan hukum dilakukan dengan teknik penelusuran kepustakaan. Agar awig-awig yang diteliti representatif mewakili Bali, maka dicari awig-awig desa pakraman yang secara representatif mewakili kabupaten-kabupaten yang ada di Bali. Bahan hukum sekunder dan bahan non hukum dicari dan dikumpulkan melalui penelusuran literatur di perpustakaan dan internet.. Informasi yang diperoleh dari bahan-bahan hukum tersebut di-fotocopy dan atau dicatat dengan menggunakan metode pencatatan model sistem kartu (cardsystem).

Setelah diolah dan dianalisis dengan teknik-teknik penalaran dan argumentasi hukum yang relevan, akhirnya keseluruhan hasil penelitian disajikan secara deskriptif analisis.

\section{HASIL DAN PEMBAHASAN \\ 3.1. Ruang Lingkup Hukum Keluarga dalam Awig-awig Desa Pakraman.}

Dari penelitian terhadap awigawig desa pakraman dapat diketahui bahwa awig-awig desa pakraman mengatur aspek-aspek hukum keluarga dalam satu bab (sarga) tersendiri, yaitu 
yaitu dalam bab (sarga) yang berjudul Sukerta Tata Pawongan. Ruang lingkup hukum keluarga yang diatur dalam bab ini meliputi:
(1) Prihal perkawinan (indik pawiwahan)

(2) Prihal perceraian (indik nyapian)

(3) Prihal keturunan (indik sentana); dan
(4) Prihal pewarisan (indik warisan).

Berikut ini akan diuraikan pengaturan masing-masing substansi aspek-aspek hukum keluarga tersebut.

\subsection{Pengaturan Aspek Hukum Perkawinan (Pawiwahan)}

Dalam masyarakat adat Bali, terdapat beberapa istilah yang digunakanuntukmenyebutperkawinan, diantaranya: nganten, masomahan, makurenan, alakirabi, mekerabkambe, merabian, pawiwahan, dan lainlain $^{10}$. Dari hasil penelitian diketahui bahwa istilah teknis yang digunakan dalam awig-awig desa pakraman untuk menyebut perkawinan adalah "pawiwahan". Masalah perkawinan diatur pada bagian (palet) khusus di bawah titel Indik Pawiwahan yang pada umumnya mengatur aspek-aspek sebagai berikut:

(1) Pengertian perkawinan;

(2) Cara dan bentuk perkawinan (pemargin pawiwahan)

10 I Ketut Sudantra, I Gusti Ngurah Sudiana dan Komang Gede Narendra, 2011, Perkawinan Menurut Hukum Adat Bali, Denpasar: Udayana University Press, hlm. 3.
(3) Syarat-syarat perkawinan (pidabdab sang pacang mawiwaha)

(4) Prosedur perkawinan (pemargin pawiwahan)

\section{Ad. 1. Pengertian Perkawinan}

Hampir semua awig-awig desa pakraman yang diteliti mengatur secara eksplisit mengenai difinisi perkawinan. Dari sembilan awigawig desa pakraman yang diteliti hanya ditemukan satu awig-awig yang tidak memberikan rumusan difinisi perkawinan, yaitu Awig-awig Desa Pakraman Gadungan (Tabanan). Tetapi dari penelitian terhadap pasalpasal yang terdapat dalam bagian (palet) indik pawiwahan, dapat dipahami bahwa konsep perkawinan yang dianut dalam Awig-awig Desa Pakraman Gadungan tidak berbeda dengan konsep perkawinan yang diatur oleh awig-awig yang lain.

Temuan penelitian juga menunjukkan bahwa terdapat keseragaman mengenai rumusan difinisi perkawinan. Sebagai contoh, dapat ditunjuk perumusan difinisi perkawinan yang ditentukan dalam Pawos 52 Awig-awig Desa Adat Bangklet (Bangli). Secara lengkap, pawos tersebut menentukan bahwa "Pawiwahan inggih punika petemoningpurusapredanamelarapan panunggalan kayun cuka cita maduluran upasaksi sekala niskala" Rumusan yang persis sama ditemukan dalam Pawos 49 Awig-awig Desa 
Adat Badingkayu (Jembrana), Pawos 68 Awig-awig Desa Adat Unggasan (Badung), dan Pasal 50 Awigawig Desa Adat Geriyana Kangin (Karangasem). Rumusan yang sedikit berbeda ditemukan dalam Pawos 68 Awig-awig Desa Adat Jungutbatu (Klungkung) yang menambahkan frasa "laki istri" setelah frasa "purusa lan pradana", untuk menegaskan bahwa istilah "purusa-pradana" menyangkut jenis kelamin para pihak yang melakukan perkawinan

Walaupun ditemukan terdapat variasi-variasi tertentu dalam kalimatnya, dapat ditegaskan secara umum bahwa difinisi perkawinan menurut awig-awig desa pakraman adalah suatu ikatan antara laki-laki (purusa) dan perempuan (pradana) yang didasarkan atas perasaan suka sama suka, yang dilakukan melalui rangkaian upacara agama yang disaksikan oleh masyarakat dan roh leluhur ("upasaksi sakala-niskala)".

Ad 2. Cara dan bentuk perkawinan

Selain mengatur mengenai difinisi perkawinan, awig-awig desa pakraman juga mengatur tentang cara perkawinan. Yang dimaksud dengan cara di sini adalah proses awal perkawinan. Seperti diketahui, dalam hukum adat Bali dikenal dua cara perkawuinan dilakukan, yaitu (1) perkawinan memadik (pepadikan) yaitu perkawinan yang dilakukan dengan cara meminang;; (2) perkawinan ngerorod (merangkat), yaitu perkawinan yang dilakukan dengan cara lari bersama (kawin lari) ${ }^{11}$. Sesuai dengan sistem kekeluargaan yang dianut dalam masyarakat hukum adat di Bali, dalam hukum adat Bali semula ditemukan dua bentuk perkawinan, yaitu (1) perkawinan biasa; yaitu perkawinan di mana pihak istri (yang berstatus pradana) meninggalkan keluarga asalnya (orang tua dan saudara-saudara sekandung) selanjutnya masuk mengikuti keluarga suami (pihak purusa); dan perkawinan nyeburin (nyentana), yaitu perkawinan di mana si suami (yang berstatus pradana) meninggalkan keluarga asalnya (orang tua dan saudara sekandungnya). Belakangan, ditemukan bentuk perkawinan ketiga, yaitu bentuk perkawinan di mana pihak suami ataupun istri masing-masing tetap berstatus sebagai bagian dari keluarganya masing-masing. Bentuk perkawinan ini disebut perkawinan pada gelahang, nadua umah, atau istilah lain ${ }^{12}$

Hasil penelitian menunjukkan bahwa awig-awig desa pakraman tidak membedakan antara konsep cara dengan konsep bentuk perkawinan. Baik cara maupun bentuk perkawinan dirumuskan dalam satu uraian pasal

Wayan P. Windia dan Ketut Sudantra, op.cit., hlm. 85 .

12 I Ketut Sudantra, I Gusti Ngurah Suriana, dan Komang Gede Narendra, op.cit., hlm.610.; Lihat juga, Putu Dyatmikawati, 2013, Kedudukan Hukum Perkawinan Pada Gelahang, Denpasar: Fakultas Hukum Universitas Dwijendra-Udayana University Press, hlm. 137-139. 
(pawos). Misalnya, Pawos 52 Awigawig Desa Adat Bangklet (Bangli) menentukan sebagai berikut:

Pemargin Pawiwahan, luwire:

(1) Pepadikan;

(2) Ngerorod;

(3) Nyeburin

Kalau diterjemahkan secara bebas, pasal tersebut menguraikan tentang pelaksanaan perkawinan yang meliputi (1) meminang, (2) kawin lari; dan (3) perkawinan di mana suami ikut istri(nyeburin). Ketentuan yang sama diatur dalam Pawos 50 Awigawig Desa Adat Geriyana Kangin; Pawos 68 Awig-awig Desa Adat Jungutbatu, dan lain-lain. Berbeda dengan awig-awig yang lain, Awigawig Desa Adat Penarukan hanya mengatur satu cara perkawinan, yaitu petrkawinan ngerorod. Mengenai bentuk perkawinan pada gelahang, hanya ditemukan satu awig-awig yang mengaturnya, yaitu Awig-awig Desa Pakraman Gadungan yang menyebut bentuk perkawinan ini dengan sebutan perkawinan nadua umah.

\section{Ad. 3. Syarat-syarat perkawinan}

Dalamawig-awigdesapakraman juga diatur menganai syarat-syarat perkawinan. Adapun mengenai syaratsyarat perkawinan tersebut, adalah sebagai berikut:

a. Sudah dewasa (sampun manggeh deha teruna)

b. Berdasarkan kehendak para pihak (sangkaning pada renal tan kapaksa) c. Sesuai dengan ketentuan agama (nganutin kecaping ahama)

d. Tidak berhubungan darah dekat((tan gamia gemana)

e. Dilakukan upacara suda wadani dalam hal pasangan berbeda agama(kawisudayang prade pengambile sios agama miwah kapatiwangi);

f. Pelaksanaan perkawinan juga mengikuti Undang-undang Perkawinan yang dikeluarkan oleh pemerintah (pamargin pawiwahan mangda taler nganutin Undang-undang Perkawinan saking sang mawarat).

Di samping syarat-syarat tersebut, awig-awig desa pakraman juga mengatur mengenai syarat sahnya perkawinan (pengesahan perkawinan). Awig-awig menyebut konsep sah dengan istilah kapatutang (pawiwahan sane kapatutang) sedangkan tidak sah disebut tan patut. Hasil penelitian menunjukkan bahwa menurut awigawig desa pakraman, perkawinan dianggap sah (kapatutang) apabila sudah dilaksanakan rangkaian upacara agama (pabyakala, pasakapan, dan kapajatiang ring Kahyangan Desa) dan disaksikan oleh kepala adat (prajuru). Awig-awig desa pakraman juga menentukan bahwa perkawinan wajib dimuat dalam catatan perkawinan di desa pakraman dan juga dicatatkan dalam catatan perkawinan Pemerintah. 


\section{Ad. 4. Prosedur Perkawinan}

Aspek prosedur perkawinan juga diatur dalam awig-awig desa pakraman, baik yang dilakukan dengan cara meminang maupun kawin lari. Pada prinsipnya, apapun cara yang ditempuh, semua awigawig yang diteliti menentukan bahwa setiap orang yang akan melakukan perkawinan terlebih dahulu wajib mesadok (melapor, memberitahukan) kehendaknya untuk kawin kepada kepala adat (Prajuru) dan kepala adat selanjutnya memastikan apakah perkawinan tersebut sesuai atau tidak sesuai dengan ketentuan yang berlaku.

Hasil penelitian juga menunjukkan bahwa terdapat adanya perbedaan prosedur dalam perkawinan meminang (mepadik) dengan kawin lari (ngerorod). Dalam perkawinan meminang (pepadikan) proses perkawinan didahului dengan pembicaraan-pembicaraan antara keluarga calon pasangan pengantin, dengan inisiatif dari keluarga calon mempelai laki-laki. Acara ini disebut makruna (meminang). Ditemukan variasi-variasi mengenai berapa kali acara ini dilakukan, ada yang menentukan dilakukan sekali, ada yang menentukan dua kali, atau tiga kali. Sarana yang digunakan pun bervariasi. Dalam perkawinan ngerorod proses perkawinan diawali dengan dilarikannya calon mempelai perempuan oleh calon mempelai lakilaki. Dalam proses ini, semua awigawig yang diteliti menentukan bahwa tidak diperkenankan mengajak calon mempelai perempuan langsung ke rumah mempelai laki-laki sebelum diadakan upacara pengesahan perkawinan (pabyakalan). Setelah proses "melarikan" ini terjadi, segera ditindaklanjuti oleh keluarga calon mempelai laki-laki dengan mengutus sekurang-kurangnya dua orang utusan ke rumah orang tua si perempuan untuk memberitahukan bahwa anak gadisnya sudah dilarikan untuk dikawini oleh calon mempelai laki-laki. Dalam awigawig, acara ini disebut dengan istilah pamiluku atau mepejati.

\subsection{Pengaturan Aspek Hukum Perceraian (Nyapian)}

Awig-awig yang diteliti juga mengaturaspek-aspek hukum dibidang perceraian. Istilah yang digunakan dalam awig-awig adalah nyapian atau palas perabian. Aspek-aspek yang diatur terkait dengan perceraian ini adalah, sebagai berikut: (1) sebabsebab putusnya perkawinan; (2) dasar (sebab) terjadinya perceraian; (3) prosedur perceraian; (4) sanksi-sanksi dalam perceraian.

Mengenai sebab putusnya perkawinan, awig-awig menyebutkan ada dua sebab, yaitu perkawinan putus karena perceraian (palas marabian), dan perkawinan putus karena kematian salah satu pihak (kapademan). Sedangkan mengenai dasar perceraian, awig-awig umumnya menyebut dua hal, yaitu: (1) karena kehendak bersama (sangkaning pada lila); (2) karena adanya masalah 
antara suami-istri (mawiwit wicara). Prosedur pelaksanaan perceraian terlebih dahulu wajib diberitahukan secara tertulis kepada Pemerintah, dalam hal ini Pengadilan sehingga jelas ada keputusan tentang perceraian tersebut (atur supeksa pailikitan ring sang Ngawiwenang wastu tinas apadang pamutuse kabawos nyapian). Setelah ada keputusan dari Pengadilan kemudian Prajuru (pengurus adat) mengumumkan perceraian tersebut kepada warga desa adat melalui paruman (rapat) desa (Prajuru Desa nyobyahang kawentanya ring paruman desa).Beberapaawig-awigmenentukan bahwa pihak yang bercerai dikenakan sanksi adat sesuai dengan keputusan desa yang bersangkutan (keni panebas swaran kulkul manut pararem).

\subsection{Pengaturan Aspek Hukum Tentang Keturunan (Sentana)}

Keturunan adalah orang yang meneruskan kelangsungan suatu keluarga. Dalam awig-awig desa pakraman, prihal keturunan diatur dalam Bab (Sarga) Sukerta Tata Pawongan, khususnya pada Bagian (Palet) Indik Sentana ${ }^{13}$. Secara gramatikal, sentana berarti anak atau keturunan ${ }^{14}$. VE. Korn, peneliti dan penulis Hukum Adat Bali juga menegaskan bahwa istilah

13 Ditemukan juga awig-awig desa pakraman yang tidak mengatur secara khusus prihal sentana, misalnya Awig-awig Desa Adat Penarukan.

14 Sri Resi Anandakusuma, 1986, Kamus Bahasa Bali, Denpasar: CV Kayumas, hlm. 177. sentana berarti anak keturunan yang menggantikan bapaknya sebagai kepala keluarga ${ }^{15}$.

Dalam hukum adat Bali, garis keturunan dilacak dari garis laki-laki, karenasistem kekeluargaanyang dianut oleh masyarakat bali adalah sistem kekeluargaan patrilineal yang disebut purusa atau kapurusa) ${ }^{16}$. Dari pasalpasal (pawos) awig-awig yang diteliti tidak ditemukan adanya ketentuan yang menegaskan secara ekplisit tentang sistem kekeluargaan yang dijadikan dasar pengaturan hukum keluarga dalam awig-awig desa pakraman. Namun dengan menganalisis secara cermat keseluruhan awig-awig desa pakraman, khususnya Bab (Sarga) Sukerta Tata Pawongan dapat dipastikan bahwa sistem kekeluargaan purusa menjiwai hukum keluarga yang diatur dalam awig-awig desa pakraman. Indikasi-indikasi yang dapatmenguatkan kesimpulan tersebut, antara lain dapat dilihat pada prinsipprinsip yang dianut dalam awig-awig desa pakraman, sebagai berikut:

(1) Dalam perkawinan, secara umum dianut prinsip bahwa mempelai perempuan mengikuti keluarga pihak mempelai laki-laki (istri ikut suami). Prinsip ini misalnya dapat disimpulkan dari ketentuan

15 V.E. Korn, 1978, Hukum Adat Kekeluargaan di Bali, terjemahan I Gde Wayan pangkat, Denpasar: Biro Dokumentasi dan Publikasi Hukum Fakultas Hukum \& Pengetahuan Masyarakat Universitas Udayana, hlm. 7.

16 Wayan P Windia dan Ketut Sudantra, op.cit. hlm., 78 . 
awig-awig desa pakraman yang menentukan bahwa:"... sang istri keajak budal ring pakubon sang lanang..." (mempelai perempuan diajak pulang kerumah mempelai laki-laki);

(2) Ahli waris adalah keturunan (anak) laki-laki (pratisentana purusa) atau anak perempuan yang dikukuhkan statusnya sebagai purusa (sentana rajeg), baik anak kandung maupun anak angkat.

Prinsip-prinsip di atas adalah asas hukum yang secara umum dianut dalam sistem kekeluargaan purusa.

Dalamawig-awigdesapakraman, aspek-aspek yang diatur pada Bagian (Palet) Indik Sentana adalah sebagai berikut:

(1) Jenis-jenis anak keturunan (sentana);

(2) Kedudukan anak luar kawin;

(3) Pengangkatan anak

Mengenai jenis-jenis sentana, awig-awig desa pakraman pada umumnya membedakan anak keturunan menjadi dua, yaitu anak kandun (pratisentana) dan anak angkat (sentana paperasan). Istilah pratisentana tampaknya menunjuk pada konsep anak kandung yang sah, sebab awig-awig desa pakraman mendifinisikannya sebagai "...sentana sane metu sangkaning pawiwahan sane patut" (anak yang lahir dari perkawinan yang sah). Di luar anak kandung sah, awig-awig juga mengatur tentang anak luar kawin yang disebut dengan istilah babinjat atau astra. Tetapi dalam awigawig yang diteliti tidak ada penegasan mengenai kedudukan anak luar kawin ini dalam keluarga. Beberapa awigawig yang diteliti hanya menentukan bahwa dsalam hal terjadi kelahiran anak luar kawin wajib dilakukan upacara agama tertentu yang tujuannya mengembalikan keseimbangan gaib (mengilangkan kekotoran gaib), misalnya dalam bentuk upacara yang disebut pamrayascita, panyangaskara (widi widana) miwah pras kundulan; sesipatan; dan lain-lain.

Dalam beberapa awig-awig desa pakramanjugadiaturmengenaisentana rajeg, yaitu anak kandung perempuan yang dikukuhkan statusnya purusa dan melakukan perkawinan nyeburin ("Sentana Rajeg inggih punika, pratisentana wadon (pradana) sane kamanggehang lanang (purusa) tur risampun ngelaksanayang pawiwahan nyeburin"). Hasil penelitian juga menunjukkan bahwa terdapat awigawig desa pakraman yang samasekali mengatur prihal sentana rajeg, yaitu Awig-awig Desa Adat Pgenarukan dan Awig-awig Desa Adat Geriyana Kangin. Kedua desa pakraman tersebut terakhir ini masing-masing terletak di Kabupaten Buleleng dan Kabupaten Karangasem.

Kecuali Awig-awig Desa Adat Penarukan yang memang samasekali tidak mengatur secara khusus prihal anak keturunan (sentana), semua awigawig lainnya yang diteliti mengatur prihal pengangkatan anak. Istilah- 
istilah yang digunakan untuk menyebut perbuatan hukum pengangkatan anak, antara lain: ngidih sentana, ngangkat sentana; sedangkan untuk anak angkat disebut dengan istilah sentana paperasan. Namun demikian, tidak ada satu pun awig-awig yang diteliti merumuskan difinisi konsep anak angkat ataupun pengangkatan anak. Namun demikian, dengan penafsiran konseptual dapat dipahami bahwa pengangkatan anak adalah proses menjadikan anak orang lain menjadi anak sendiri untuk meneruskan keturunan orang tua angkat.

Hasil penelitian menunjukkan bahwa aspek-aspek yang duatur dalam awig-awig desa pakraman berkaitan dengan pengangkatan anakini, meliputi prosedur pengangkatan anak; syarat anak yang diangkat dan mengenai sahnya pengangkatan anak Mengenai prosedur pengangkatan anak, pada umumnya awig-awig desa pakraman menentukan sebagai berikut:

(1) Setiap orang yang berkehendak mengangkat anak wajib melapor kepada kepala adat (Bendesa) dalam waktu terterntu sebelum pengangkatan anak

(2) Kepala adat mengumumkan kepada warga di wilayah desa pakraman mengenai rencana pengangkatan anak tersebut, kalau ada pihak yang beberatan supaya menyampaikan keberatannya kepada kepala adat dalam batas waktu tertentu

(3) Kepalaadatkemudian membahas keinginan mengangkat anak tersebut dan memberikan keputusan sesuai ketentuan yang berlaku

(4) Jika pengangkatan anak tidak sesuai prosedur di atas, kepala adat berwenang menunda upacara pengangkatan anak tersebut, memberikan tuntunan supaya semua permasalahan diselesaikan terlebih dahulu

Mengenai syarat anak yang diangkat sebagai anak angkat, awigawig desa pakraman pada umumnya menentukan bahwa orang yang dapat diangkat menjadi anak angkat adalah:

a. Orang yang beragama Hindu;

b. Dari keluarga garis bapak; kalau tidak ada dari garis bapak, boleh dari garis ibu; kalau juga tidak ada dibolehkan sekehendak hati tetapi tetap yang beragama Hindu.

Mengenai sahnya pengangkatan anak, awig-awig desa pakraman menentukan bahwa pengangkatan anak dianggap sah (paperesan sane kapatut) apabila dilakukan melalui upacara agama yang khusus untuk pengangkatan anak, yaitu widi widana peparasan; disaksikan oleh kepala adat yang akan mencatat dan mengumunkan pengangkatan anak tersebut; dan disiarkan (diumumkan) di wilayah desa pakraman.

\subsection{Pengaturan Aspek Hukum Waris \\ Pewarisan pada dasarnya suatu proses penerusan harta}


peninggalan dari satu generasi kepada generasii beikutnya. Hasil penelitian menunjukkan bahwa semua awigawig yang diteliti mengatur masalah pewarisan. Aspek hukum pewarisan diatur secara khusus dalam satu bagian (palet) dibawahbab (sarga) Pawongan dengan titel: Indik Warisan. Dalam bagian ini, aspek-aspek pewarisan yang diatur adalah sebagai berikut:

(1) Prihal harta warisan;

(2) Prihal ahli waris

(3) Prihal kewajiban ahli waris

(4) Prihal gugurnya hak mewaris

(5) Kedudukan anak perempuan dan janda

(6) Tatacara pembagian warisan

(7) Pemberian hibah kepada anak yang kawin ke luar

(8) Prihal tiadanya ahli waris

Berikut ini akan diuraikan pengaturan aspek-aspek hukum pewarisan tersebut sebagaimana ditemukan dari hasil penelitian terhadap awig-awig desa pakraman.

Prihal konsep harta warisan yang dalam awig-awig disebut dengan istilah "warisan", semua awigawig desa pakraman yang diteliti merumuskan warisan sebagai harta kekayaan dan tanggungjawab yang diperuntukkan untuk mewujudkan kesejahteraan lahir batin suatu keluarga dari nenek moyang kepada keturunannya. Rumusan demikian, misalnya, ditentukan dalam Pawos 59 Awig-awig Desa Pakraman Gadungan yang merumuskan konsep warisan sebagai berikut: "Warisan inggih punika arthabrana saha ayah-ayahan ngupadi sukerta sekala niskala saking kaluhuranya marep ring turunanya". (warisan adalah harta benda dan kewajiban-kewajiban yang ditujukan bagi kesejahteraan lahir batin dari nenek moyang kepada keturunannya) Jenis-jenis harta warisan yang diatur dalam awig-awig desa pakraman, meliputi

(1) Harta pusaka yang menjadi milik bersama (duwe tengah), baik yang mempunyai nilai ekonomi seperti sawah, ladang, termasuk tanah ayahan desa; maupun yang mempunyai nilai sakral (religio magis) seperti: tempat pemujaan keluarga (sanggah/ merajan dan pusaka-pusaka;

(2) Harta bersama (pagunakayan) yaitu harta yang diperoleh selama perkawinan berlangsung;

(3) Harta bawaan (tadtadan/ jiwadana);

(4) Utang-piutang.

Mengenai ahli waris, tidak ditemukan pengaturan mengenai difinisi konsep ahli waris dalam awigawig yang diteliti, tetapi dengan penafsiran sistematis dapat dipahami bahwa ahli waris adalah orang yang berhak menerima harta warisan. Asas ini dapat dipahami, misalnya, dari ketentuan Pawos 60 ayat (2) Awigawig Desa Pakraman Gadungan yang menyatakan bahwa "swadarmaning ahli waris, patut: ha. Nerima saha nngwasayang tetamian pahan kel uharanya..."(kewajiban ahli waris 
adalah menerima dan menguasai harta warisan..)

Awig-awig desa pakraman menentukan bahwa ahli waris meliputi: anak kandung lakilaki (pratisentana lanang), anak perempuan yang berstatus purusa (pratisentana wadon sentana rajeg), dan anak angkat (sentana paperasan). Pihak-pihak inilah yang dapat disebut sebagai ahli waris dalam kelompok keutamaan pertama. Awig-awig tidak membedakan posisi ketiga ahli waris tersebut. Dalam hal ahli waris dari kelompok keutamaan pertama ini tidak ada, maka barulah ahli waris dihitung dari kelompok keutamaan kedua, yaitu: keturunan laki-laki (purusa) dalam garis lurus ke atas, yaitu ayah, kakek, dan seterusnya. Dalam hal kelompok ahli waris keutamaan kedua ini juga tidak ada, maka yang menjadi ahli waris adalah kelompok keutamaan ketiga, yaitu keturunan purusa dalam garis menyamping, yaitu: saudara atau keponakan, saudara sepupu atau keponakan sepupu, dan seterusnya.

Di samping mengatur prihal pihak-pihak yang berstatus sebagai ahli waris, awig-awig desa pakraman juga mengatur kedudukan anak perempuan dan janda (atau duda dalam perkawinan nyeburin). Hasil penelitian menunjukkan bahwa semua awig-awig desa pakraman yang diteliti memposisikan anak perempuan dan janda dengan status bukan ahli waris (boya ahli waris). Namun demikian, awig-awig desa pakraman juga menentukan bahwa mereka mempunyai hak terbatas dan bersyarat atas harta warisan. Dikatakan mempunyai hak terbatas dan bersyarat karena mereka hanya berhak untuk menghasili (muponin) harta warisan, dengan syarat anak perempuan belum kawin ke luar (dereng kesah mawiwaha).

Ahli waris mempunyai kewajiban-kewajiban(tanggungjawab) tertentu, yang disebut swadharmaning ahli waris, yaitu:

a. Menerima dan menguasai harta warisan;

b. Bertanggung jawab terhadap tempat pemujaan keluarga (sanggah/mrajan) dan pura berikut pelaksanaan upacaranya;

c. Menggantikan kewajibankewajiban dari pewaris;

d. Melaksanakan upacara kremasi jenasah pewaris (ngaben), selanjutnya melaksanakan upacara pitra yadnya untuk roh leluhur pewaris;

e. Membayar utang-utang pewaris sesuai logika.

Dalam awig-awig desa pakraman juga diatur prihal kondisikondisi yang dapat menjadi alasan gugurnya hak mewaris dari seorang ahli waris. Kondisi-kondisi tersebut lazimnya disebut ninggal kedaton, yaitu suatu kondisi dimana seorang ahli waris mengabaikan atau meninggalkan tanggungjawabnya (swadharma-nya) di rumah keluarganya, termasuk kewajibannya 
terhadap orang tua. Pada umumnya awig-awig yang diteliti menyebutkan kondisi-kondisi yang dikwalifikasikan ninggal kedaton adalah: pindah agama (nilar kawitan lan sasananing agama Hindu), durhaka atau tidak melakukan kewajiban kepada orang tua (alpaka guru rupaka), dan kawin ke luar (kesah mawiwaha)

Pembagian harta warisan dapat terjadi apabila terdapat lebih dari satu ahli waris. Pada umumnya semua awig-awig yang diteliti menganut prinsip bahwa pembagian warisan dilakukan secara musyawarah mufakat (paigum) dalam keluarga, walaupun beberapa awig-awig yang diteliti juga memberikangaris-garistegasmengenai kedudukan masing-masing ahli waris terhadap harta warisan tertentu, misalnya untuk harta pagunakaya (harta pencaharian, harta bersama) para ahli waris mempunyai hak yang sama, sedangkan untuk tanah-tanah karang ayahan desa (tanah adat) menjadi hak ahli waris yang berstatus krama ngarep (ahli waris yang mempunyai tanggungjawab penuh kepada desa). mengenai bagian Apabila cara musyawarah gagal sehingga terjadi sengketa, maka penyelesaian dilakukan dengan menggunakan mekanisme penyelesaian perkara yang diatur dalam awig-awig desa pakraman, yaitu dengan melibatkan kepala adat (prajuru) sesuai tingkatannya. Apabila cara ini pun gagal, maka sengketa pembagian warisan dapat diselesaikan melalui Pengadilan (Sang Rumawos).
Adakalanya dalam suatu keluarga tidak terdapat ahli waris (kaputungan). Awig-awig desa pakraman pada umumnya juga sudah mengantisipasi hal ini, dengan menentukan bahwa menjadi tugas kepala adat untuk menemukan ahli waris dari garis purusa yang berhak mewarisi harta warisan tersebut. Apabila ternyata benar-benar tidak ada ahli waris yang berhak atas harta warisan, beberapa awig-awig desa pakraman menentukan bahwa harta tersebut menjadi hak desa pakraman (kedaut antuk desa).

Di samping mengatur aspekaspek hukum pewarisan, dalam artian penerusan harta warisan kepada mereka yang berstatus sebagai ahli waris, beberapa awig-awig desa pakraman yang diteliti juga mengatur prihal pemberian harta (hibah) kepada anak yang bukan berstatus sebagai ahli waris. Misalnya, dalam Pawos 85 ayat (5) Awig-awig Desa Adat Ungasan ditentukan bahwa: "Perwaris kengin maweweh rikala maurip pinaka jiwa dana, tadtadan/bekel, makacihna maweweh tetep ring pianak sane kesah mawiwaha (pewaris dapat memberikan hibah kepada anak yang kawin keluar berupa pemberian tetap sebagai jiwadana(harta untuk nafkah), tadtadan/bekal)

\section{PENUTUP}

\subsection{Simpulan}

Berdasarkan uraian di atas akhirnya dapat disimpulkan sebagai berikut: 
1. Aspek-aspek hukum keluarga diatur dalam awig-awig desa pakraman dalam satu bab (sarga) khusus yang mengatur kehidupan bersama dalam keluarga, yang diberi judul Sukertha Tata Pawongan.

2. Secara substansial, pengaturan aspek-aspek hukum keluarga yang diatur dalam awig-awig desa pakraman adalah sebagai berikut:

(1) Prihal perkawinan diatur dalam bagian (palet) indik pawiwahan yang meliputi pengaturan mengenai pengertian perkawinan; cara dan bentuk perkawinan (pemargin pawiwahan); syarat-syarat perkawinan (pidabdab sang pacang mawiwaha); dan prosedur perkawinan (pemargin pawiwahan)

(2) Prihal perceraian diatur dalam bagian (palet) indik nyapian yang di dalamnya diatur aspek-aspek tentang sebab putusnya perkawinan, dasar perceraian, prosedur perceraian, dan sanksi-sanksi dalam perceraian.

(3) Prihal anak keturunan diatur dalam bagian (palet) indik sentana yang meliputi: pengaturan tentang jenisjenis anak keturunan (sentana), kedudukan anak luarkawin; dan pengangkatan anak;

(4) Prihal pewarisan diatur dalam bagian (palet) indik warisan yang di dalamnya diatur aspek-aspek tentang harta warisan; prihal ahli waris, kewajiban ahli waris, gugurnya hak mewaris, kedudukan anak perempuan danjanda,tatacarapembagian warisan, pemberian hibah kepada anak yang kawin ke luar, dan prihal tiadanya ahli waris

\subsection{Saran}

Penelitian ini baru sampai pada tahap identifikasi hukum, yaitu identifikasi norma-norma hukum keluarga di dalam awig-awig desa pakraman. Kepada para peneliti disarankan untuk melanjutkan penelitian ini dengan penelitian terhadap asas-asas hukum yang terkandung dalam norma-norma tersebut. Dengan begitu, diharapkan dapat diidentifikasi pula nilai-nilai hukum adat Bali universal yang berlaku dalam masyarakat. Di samping itu, penelitian ini adalah penelitian hukum normatif yang hanya meneliti normanoorma hukum adat Bali sebagaimana tertulis dalam kitab yang belum tentu menggambarkan perilaku hukum masyarakat dalam kenyataannya. Karena itu, penelitian hukum empiris perlu dilakukan untuk mengetahui apakah norma-norma hukum keluarga sebagaimana yang tertulis dalam awig- 
awig desa pakraman dipraktekkan atau sebaliknya dalam kehidupan tanya masyarakat desa pakraman yang bersangkutan.

\section{DAFTAR PUSTAKA}

\section{A. Buku:}

Anandakusuma Sri Resi, 1986, Kamus Bahasa Bali, CV Kayumas, Denpasar,

Badan Perencanaan Pembangunan Daerah Bali Pemerintah Provinsi Bali, 2015, Data Bali Membangun 2014

Dyatmikawati Putu, 2013, Kedudukan Hukum Perkawinan Pada Gelahang, Fakultas Hukum Universitas Dwijendra-Udayana University Press, Denpasar.

Biro Hukum Setda Provinsi Bali, 2001, Pedoman/Teknis Penyusunan Awig-awig dan Keputusan Desa Adat

Korn V.E., 1978, Hukum Adat Kekeluargaandi Bali, terjemahan

I Gde Wayan Pangkat, Biro Dokumentasi dan Publikasi Hukum Fakultas Hukum \& Pengetahuan Masyarakat Universitas Udayana, Denpasar.

Sudantra I Ketut, I Gusti Ngurah Sudiana, dan Komang Gede Narendra, 2011, Perkawinan Menurut Hukum Adat Bali, Udayana University Press, Denpasar

Sudiana I Gusti Ngurah dan I Made Artha, 2006, Samhita Bhisama Parisada Hindu Dharma
Indonesia, Parisada Hindu Dharma Indonesia Provinsi Bali, Denpasar.

Windia Wayan P. dan Ketut Sudantra, 2006, Pengantar Hukum Adat Bali, Lembaga Dokumentasi dan Publikasi Fakultas Hukum Universitas Udayana, Denpasar.

\section{B. Awig-awig Desa Pakraman:}

Awig-awig Desa Adat Badingkayu, Jembrana (Masehi 1995)

Awig-awig Desa Adat Bangklet, Bangli (Masehi 1996)

Awig-awig Desa Adat Belega, Gianyar (Masehi 1995)

Awig-awig Desa Adat Geriyana Kangin, Karangasem (Isaka 1908)

Awig-awig Desa Adat Jungutbatu, Nusa Penida, Klungkung(tanpa tahun)

Awig-awig Desa Adat Pedungan, Denpasar (Masehi 1986)

Awig-awig Desa Adat Penarukan, Buleleng (Maehi1986)

Awig-awig Desa Adat Ungasan, Badung (Masehi 1991).

Awig-awig desa Pakraman Gadungan, Tabanan (Masehi 2004) 